\title{
Clinical Features of Viral Hepatitis : Infection, Immunology, Strategy ${ }^{* *}$
}

\author{
Fumihiro Ichida*
}

Although some studies made in the 1940's suggested that hepatitis was caused by viruses, hepatitis viruses were not detected for a long time. After Australia antigen was discovered by Blumberg et al, ${ }^{1)}$ in 1965 , studies concerning hepatitis viruses advanced remarkably. While the association of Australia antigen with hepatitis B was demonstrated, hepatitis A virus was identified by Finestone et $\mathrm{al}^{2)}$ in 1973 . However, characterization of non-A, non-B hepatitis virus has not yet been accomplished. The clinical features of viral hepatitis, including prevention, are presented in this paper.

\section{Hepatitis $\mathbf{A}$}

1. Hepatitis $A$ virus and its antigen-antibody system

Hepatitis A virus (HAV) has been isolated from the stools of patients with hepatitis $\mathrm{A}$, and it is a $27 \mathrm{~nm}$ spherical, nonenveloped virus containing RNA. HAV belongs to the picornavirus group and is an enterovirus.

HAV can be detected in the stools of patients with hepatitis A from about 10 days before the onset to just after it. Several days after the onset, anti-HAV (IgM) becomes positive in the serum and persists for three months. Anti-HAV (IgG) develops four weeks after the onset and shows a peak at three months after the acute phase, and its production continues for a long time. Therefore, serologic diagnosis of hepatitis $\mathrm{A}$ can be made by demonstrating positive anti-HAV (IgM) in serum obtained during the actue phase of the illness.

\section{Epidemiology}

The incidence of $\mathrm{HAV}$ infection varies in different geographic areas. This variation is mainly a result of hygienic factors. The prevalence of anti-
HAV is low in northern European countries even in among people in their 40's, but very high among children in Southeast Asia. In Japan, the prevalence is intermediate between them. Age-specific prevalence of anti-HAV in Japan showed a $50 \%$ positive rate among 35-year-old in 1979 and among 41-year-old in 1985 (Fig. 1). Therefore, many epidemics of hepatitis A in Japan have occurred in children at nursery schools, elementary schools and institutions for mentally retarded children.

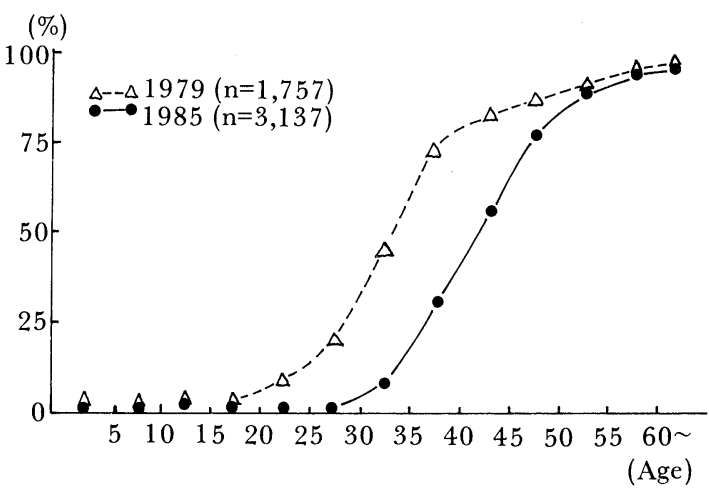

Fig. 1. Age specific prevalence of anti-HAV in Japan.

Table 1. Incidence of Sporadic Acute Viral Hepatitis in Japan.

\begin{tabular}{|c|c|c|c|c|c|c|}
\hline & & A & & $\mathrm{B}$ & NANB & Total \\
\hline 1982 & 98 & (33.9) & 85 & $(29.4)$ & $106(36.6)$ & 289 \\
\hline 1983 & 502 & $(57.7)$ & 127 & (14.6) & $240(27.6)$ & 869 \\
\hline 1984 & 180 & $(29.5)$ & 155 & $(25.5)$ & $274(45.0)$ & 609 \\
\hline \multirow[t]{2}{*}{1985} & 89 & (15.9) & 182 & $(32.4)$ & $290 \quad(51.7)$ & 561 \\
\hline & 869 & $(37.3)$ & 549 & $(23.6)$ & $910(39.1)$ & 2328 \\
\hline
\end{tabular}

*Professor, The Third Department of Internal Medicine, Niigata University School of Medicine, Niigata.

**Presented at the 83rd Annual Scientific Session of the Japanese Society of Internal Medicine, held on April 5, 1986, in Tokyo. 
In 1983, many outbreaks of hepatitis A were recognized in our country (Table 1), and part of them were caused by consuming raw oysters contaminated with HAV.

\section{Prevention}

The highest risk source of infection is the stools of patients during the incubation period and acute illness. Patients saliva is also an infectious source. Water and various foods contaminated with HAV transmit hepatitis A. Transmission of hepatitis A by eating raw oysters has been demonstrated in the outbreak of hepatitis A in Aomori Prefecture ${ }^{3)}$.

Prevention of hepatitis A with immune globulin is recommended for outbreaks at specific institutions for children such as described above. Immune globulin on the market at present includes antiHAV adequate for prevention of hepatitis A. Intramuscular administration of immune globulin at the dose of $0.05 \mathrm{ml} / \mathrm{kg}$ is encouraged. In our study, 141 children in a nursery school, in which two children developed hepatitis $\mathrm{A}$, were injected with immune globulin, and none of them developed hepatitis A thereafter. This fact suggests the usefulness of immune globulin for the prevention of hepatitis A.

The most reliable prevention is vaccination. Many studies on hepatitis A vaccine are underway but there is still no available vaccine. In vitro propagation of HAV is necessary for the development of hepatitis A vaccine. Propagation of HAV in FL cells, Vero cells ${ }^{4)}$ and hybrid cells of marmoset hepatocytes and Vero cells (Fig. 2) has been demonstrated in our studies.

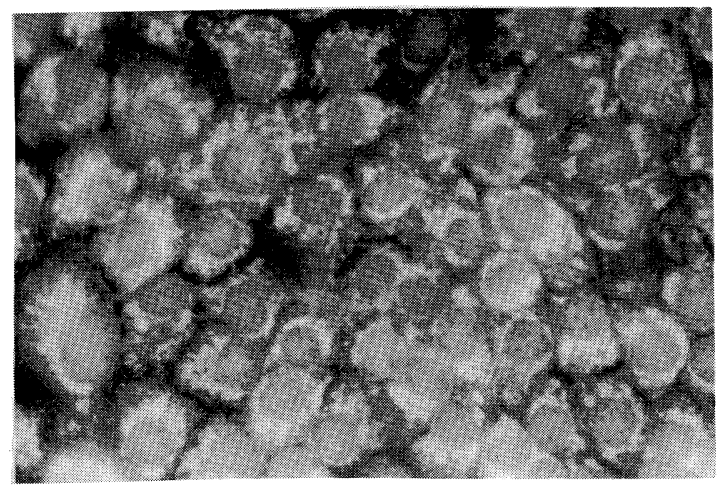

Fig. 2. HAV propagation in hybrid cells observed by immunofluorescent antibody technique.

\section{Hepatitis $B$}

\section{Hepatitis $B$ virus and its serum markers}

There are three forms of hepatitis $B$ virus (HBV)-associated particles in the serum of HBVinfected patients. Small spherical particles $(22 \mathrm{~nm}$ in diameter) and rod-shaped particles $(22 \mathrm{~nm}$ wide) do not contain DNA and are incomplete viral coat protein detected as $\mathrm{HBs}$ antigen in serum. Dane particles (42 $\mathrm{nm}$ in diameter) are the complete $\mathrm{HB}$ virion and consist of an internal core (27 $\mathrm{nm}$ in diameter) and envelope. The internal core contains DNA and is detected as $\mathrm{HBc}$ antigen after treatment with detergents. The envelope of the Dane particles has $\mathrm{HBs}$ antigen. HBe antigen in the serum is considered to be associated with the component of the core particle.

\section{HBV replication in liver cells}

Electron microscopic observations in 30 cases of HBsAg-positive liver disease and 12 asymptomatic carriers of $\mathrm{HBV}$ suggested the following mechanism of intracellular development of Dane particles: core particles migrate from the nucleus into the cytoplasm through the nuclear pores. Intracytoplasmic core particles protrude into the cisternae of the endoplasmic reticulum by budding, therefore the outer coat of Dane particles is derived from the membrane of the endoplasmic reticulum ${ }^{5)}$. Dane particles in the hepatocytes were detected in 14 of 15 cases positive for serum $\mathrm{HBeAg}$, while no particles were seen in $27 \mathrm{HBeAg}$ negative cases, thus suggesting that serum $\mathrm{HBeAg}$ reflected ongoing replication of hepatitis $B$ virus in the hepatocytes.

\section{HBV infection}

\section{1) Transmission of $\mathrm{HBV}$}

Transmission of HBV by blood transfusion has been remarkably reduced since donor blood began to be tested by more sensitive methods for $\mathrm{HBs} \mathrm{Ag}$. Therefore, percutaneous or parenteral transmission is the main route of $\mathrm{HBV}$ infection. The most frequent transmission mode in 57 cases of acute type B hepatitis in our hospital was percutaneous transmission that occurred accidentally among medical staff personnel. Body substances other than blood, such as saliva, urine, stools or semen, also have $\mathrm{HBs}$ antigen. HBs antigen was detected in the saliva of 16 out of $18 \mathrm{HBV}$ carriers in our study. This fact suggests the possibility of transmission 
by contact-association via body substances other than blood.

\section{2) Acute infection and persistent infection}

Almost all cases of HBV infection in adults are acute (transient) infection and do not develop HBV carriers. HBs antigen in the serum disappears six to seven weeks after the onset, and anti-HBs becomes positive three to six months after the onset. HBV-DNA, DNA-polymerase and HBe antigen are detected during acute illness.

Chronic (persistent) HBV infection occurs with perinatal transmission, usually from mother to infant. Infants born to HBV carrier mothers were examined as to whether perinatal transmission of $\mathrm{HBV}$ occurred in relation to $\mathrm{HBe}$ antigen positivity in their mothers during at least 12 months after birth (Table 2). This investigation revealed that 57 out of $67(85.1 \%)$ infants born to $\mathrm{HBe}$ antigen positive mothers developed $\mathrm{HBV}$ carriers within four months after birth. On the other hand, a very low incidence of HBV carriers was observed in infants born to $\mathrm{HBe}$ antigen negative or anti-HBe positive mothers.

\section{3) Immunology of HBV infection}

The mechanism of liver cell necrosis by HBV infection has been interpreted by cellular immunity. The cytotoxic effect of $\mathrm{T}$ and non-T cell fractions on autologous hepatocytes was separately investigated by a microcytotoxicity system in 18 patients with chronic active hepatitis ${ }^{6}$. This study suggests that cytotoxic $\mathrm{T}$ cells play an important role in hepatocellular necrosis and HLA antigen and $\mathrm{HBsAg}$ are regarded as traget antigens for these $\mathrm{T}$ cells. Chronic HBV infection may be caused by inadequate responses of $\mathrm{T}$ cells and $\mathrm{B}$ cells to HBs antigen.

Table 2. Vertical Transmission of HBV (Untreated Group)

\begin{tabular}{|c|c|c|c|c|}
\hline Mother & \multicolumn{4}{|c|}{ Children } \\
\hline $\begin{array}{l}\mathrm{HBeAg} / \\
\text { anti-HBe }\end{array}$ & $\begin{array}{l}\mathrm{HBsAg} \\
\text { anti-HBs }\end{array}$ & + & $+^{*}$ & $\overline{+}=$ \\
\hline$+/-67$ & & $\begin{array}{c}57 \\
(85.1 \%)\end{array}$ & ${ }^{1}(10.4 \%)$ & $6 \begin{array}{l}3 \\
(4.5 \%)\end{array}$ \\
\hline$-/-63$ & & $\left(\begin{array}{c}1 \\
(1.6 \%)\end{array}\right.$ & ${ }^{1}(15.9 \%)$ & $9_{(82.5 \%)}^{52}$ \\
\hline$-1+86$ & & 0 & ${ }^{0}(2.3 \%)$ & $\begin{array}{l}284 \\
(97.7 \%)\end{array}$ \\
\hline
\end{tabular}

*: transiently positive

\section{Prevention}

1) Immune globulin prophylaxis

Medical personnel are one of the highest risk groups to be exposed to HBV infection. Thus, we administered immune globulin containing high titer anti-HBs (HBIG) to 408 medical staff members accidentally exposed to HBV infection and recognized acute type $B$ hepatitis in only two cases among them (Table 3). This suggests the usefulness of HBIG in the prophylaxis against accidental exposure. Anti-HBs passively obtained is detectable for about three months.

\section{2) Hepatitis B vaccine}

Many kinds of $\mathrm{HB}$ vaccine, such as human plasma vaccine, recombinant vaccine or synthetic peptide vaccines, have been studied, and plasmaderived vaccine is now available.

Anti-HBs response after $\mathrm{HB}$ vaccine administration was investigated in 596 persons and anti-HBs was detected in 533 (89\%) after three injections (Table 4). Furtehrmore, anti-HBs response was seen in $97.6 \%$ of females, but $80.3 \%$ of males after three injections. In particular, males more than 60 years old showed a low anti-HBs response of $46.2 \%$.

3) Prevention of maternal transmission by $\mathrm{HB}$ vaccine

In our country the most important area for prevention of $\mathrm{HBV}$ transmission is maternal transmission. We carried out passive-active immunization for prevention of maternal transmission, that is, two injections of HBIG within two months after birth and three administrations of $\mathrm{HB}$ vaccine after HBIG within five months. In comparison

Table 3. HBIG Prophylaxis in Accidental Infection of Medical Personnel

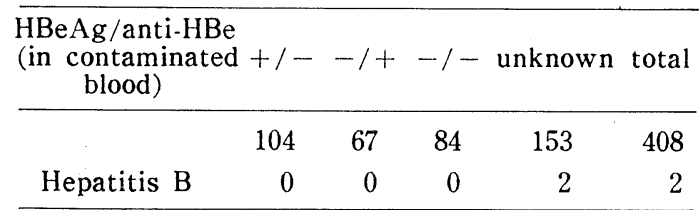

Table 4. Anti-HBs Response after Administration of HB Vaccine

\begin{tabular}{ccccccc}
\hline \multirow{4}{*}{ Total } & $0^{*}$ & $4^{*}$ & 8 & 14 & $20 *$ & $24-28 \mathrm{w}$ \\
\cline { 2 - 6 } & $0 / 762$ & $\begin{array}{c}225 / 708 \\
(32 \%)\end{array}$ & & $466 / 690$ & $533 / 596$ \\
& & & $(68 \%)$ & $(89 \%)$ \\
\hline
\end{tabular}




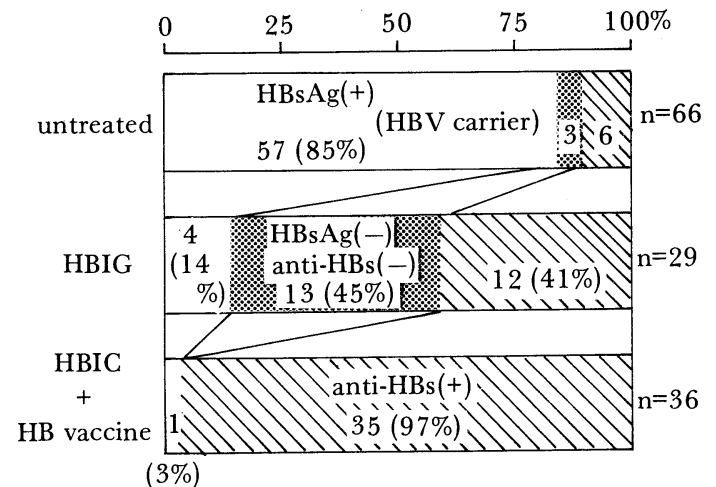

Fig. 3. Prevention of vertical transmission with HBIG and $\mathrm{HB}$ vaccine.

with the incidence of carriers in untreated infants $(85 \%)$ born to $\mathrm{HBe}$ antigen positive mothers, a remarkable reduction of $\mathrm{HBV}$ carrier infants $(3 \%)$ was observed with this strategy (Fig. 3).

\section{Therapy for chronic type $B$ hepatitis}

In the pathogenesis of liver cell damage, HBs antigen is one of the most important antigens as the target of cytotoxic $\mathrm{T}$ cells. Therefore, the interaction between active replication of $\mathrm{HB}$ virus and $\mathrm{T}$ lymphocytes plays the principal role in the prognosis of chronic type B hepatitis. Consequently, inhibition of $\mathrm{HB}$ virus replication is the most reasonable therapy today. One of two attempts in the therapy for chronic type B hepatitis is application of antiviral agents such as interferon or adenine arabinoside (Ara-A), and the other is immunomodulation by short-term corticosteroid withdrawal therapy, cianidanol, streptococcal prepara- tion, interleukin-2 or others. The results of therapy with interferon, Ara-A and steroids are shown in Table 5. Loss or transient declines of DNA polymerase and disappearance or seroconversion of $\mathrm{HBe}$ antigen were observed more frequently during and just after the end of treatment with interferons or Ara-A than in pretreatment of the patients with chronic type B hepatitis. A similar effect on $\mathrm{HBe}$ antigen was recognized in the groups that received immunomodulation therapies. A new regimen, however, will be necessary to obtain permanent loss of $\mathrm{HB}$ virus markers, such as DNA polymerase activity, HBV-DNA, HBe antigen and $\mathrm{HBs}$ antigen, from the serum.

\section{6. $\delta$ agent}

Delta agent was discovered by Rizzetto et al. in $1977^{7)}$. Delta antigen and anti- $\delta$ are detected in the serum of HBV carriers, and $\delta$ antigen is also found in liver cell nuclei of the patients infected with $\delta$ agent. Furtehrmore, $\delta$ agent is considered to cause additional hepatitis under the helper functions of HBV. The prevalence of anti- $\delta$ varies according to geographical location.

To clarify the prevalence of $\delta$ infection in Japan, $90 \mathrm{HBV}$ carriers were tested for anti- $\delta$, but only one, who died of fulminant haptic failure after blood transfusion, was demonstrated to have $\delta$ infection. Thus, $\delta$ infection in HBV carriers still has a low incidence in Japan at present.

\section{Non-A, non-B hepatitis}

There is no evidence for the identification of an etiologic agent for non-A, non-B hepatitis.

Table 5. Results of Interferon, Ara-A and Steroid withdrawal therapy for chronic hepatitis B virus infection

\begin{tabular}{|c|c|c|c|c|}
\hline drug & $\begin{array}{l}\text { Interferon } \\
n=27\end{array}$ & $\begin{array}{l}\text { Ara-A } \\
n=7\end{array}$ & $\begin{array}{l}\text { Steroid } \\
\mathrm{n}=10\end{array}$ & $\begin{array}{l}\text { Total } \\
\mathrm{n}=44\end{array}$ \\
\hline method & i. $v$ or i.m & i. $v$ & p. $o$ & \\
\hline dose & $91-630^{\mathrm{a}}$ & $3.0-18.5^{\mathrm{b}}$ & $0.735^{\mathrm{b}}$ & \\
\hline \multicolumn{5}{|c|}{ loss of DNAP } \\
\hline just after end of therapy & $13 / 27(48.1)$ & $5 / 7 \quad(71.4)$ & $0 / 7(0)$ & $18 / 40(43.9)$ \\
\hline 1 month & $6 / 27(22.2)$ & $3 / 7 \quad(42.8)$ & $3 / 7(42.8)$ & $12 / 41(29.3)$ \\
\hline 6 month & $7 / 25(28.0)$ & $1 / 6 \quad(28.5)$ & $3 / 7(42.8)$ & $11 / 38(28.9)$ \\
\hline \multicolumn{5}{|c|}{ loss of $\mathrm{HBeAg}$} \\
\hline just after end of therapy & $2 / 27(7.4)$ & $1 / 7(14.2)$ & $1 / 10(10)$ & $4 / 44(9.0)$ \\
\hline 6 month & $4 / 26(15.4)$ & $0 / 5(0)$ & $4 / 10(40.0)$ & $8 / 41 \quad(19.5)$ \\
\hline 12 month & $\begin{array}{l}5 / 18(27.8) \\
\text { SC } 3 \text { cases }\end{array}$ & $\begin{array}{l}1 / 5(20.0) \\
\mathrm{SC} 1 \text { case }\end{array}$ & $\begin{array}{l}4 / 10(40.0) \\
\text { SC } 2 \text { cases }\end{array}$ & $\begin{array}{l}10 / 33(30.3) \\
\mathrm{SC}(18.2)\end{array}$ \\
\hline
\end{tabular}

( ): \%; SC: Seroconversion from HBeAg to anti-HBe; ${ }^{a}: \times 10^{6} \mathrm{IU} ;{ }^{b}$ : grm 
Some facts proved in both human and animal studies are as follows. Blood donors who have infectious agents of non-A, non-B hepatitis in their blood are recognized through posttransfusion hepatitis. Non-A, non-B hepatitis agent is transmissible to chimpanzees and can develop the passage in chimpanzees. Furthermore, peculiar cytoplasmic tubular structures are observed in liver cells of chimpanzees by electron microscopy ${ }^{8)}$.

In our studies, marmosets have also been found to be susceptible to non-A, non-B hepatitis agent. Five marmosets were inoculated with sera of two blood donors which developed non-A, non-B hepatitis in the recipient. One of the five marmosets revealed elevation of GPT and ICD eight weeks after the inoculation (Fig. 4). Histological changes were observed during the period of enzyme eleva-

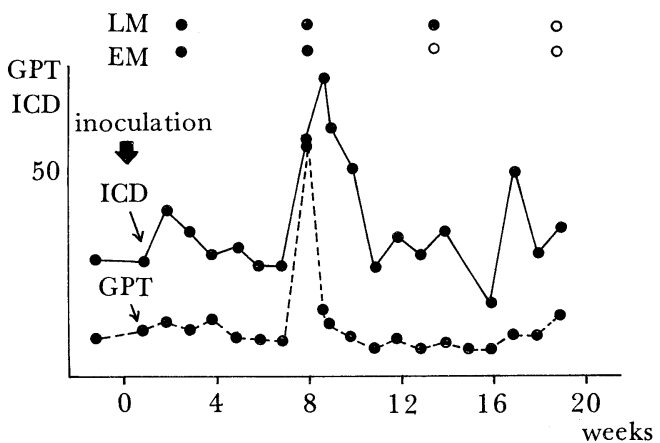

Fig. 4. Experimental infection of non-A, non-B hepatitis in marmoset NM-3. tion. Peculiar attached membrane-like structures were found in the endoplasmic reticulum of the marmoset liver cells (Fig. 5).

Although the prevention of non-A, non-B hepatitis is a difficult problem, aminotransferase and anti-HBc in donor blood have to be examined closely.

\section{REFERENCES}

1) Blumberg BS, et al: A "new" antigen in leukaemic sera. JAMA 191: 541, 1965.

2) Feinstone SN, et al: Hepatitis A: Detection by immune electron microscopy of a virus-like antigen associated with acute illness. Science 182: 1026, 1973.

3) Nara $\mathrm{H}$, et al: Epidemiological study of an outbreak of hepatitis A in Aomori Prefecture. Act Hep Jap 25: 1377, 1984.

4) Kojima H, et al: Propagation of human hepatitis A virus in conventional cell lines. J Med Virol 7: 273, 1981.

5) Kamimura T, et al: Electron microscopic studies of Dane particles in hepatocytes with special reference to intracellular development of Dane particles and their relation with $\mathrm{HBeAg}$ in serum. Hepatology 1: $392,1981$.

6) Ishihara $\mathrm{K}$, et al: Lymphocyte cytotoxicity to autologous hepatocytes in chronic active hepatitis. Act Hep Jap 26: 1427, 1985.

7) Rizzetto $\mathrm{M}$, et al: Immunofluorescence detection on new antigen-antibody system $(\delta /$ anti- $\delta)$ associated to hepatitis B virus in liver and in serum of $\mathrm{HBsAg}$ carriers. Gut 18: 997, 1977.

8) Shimizu Y, et al: Non-A, non-B hepatitis: Ultrastructural evidence for two agents in experimentally infected chimpanzees. Science 205: 197, 1979.

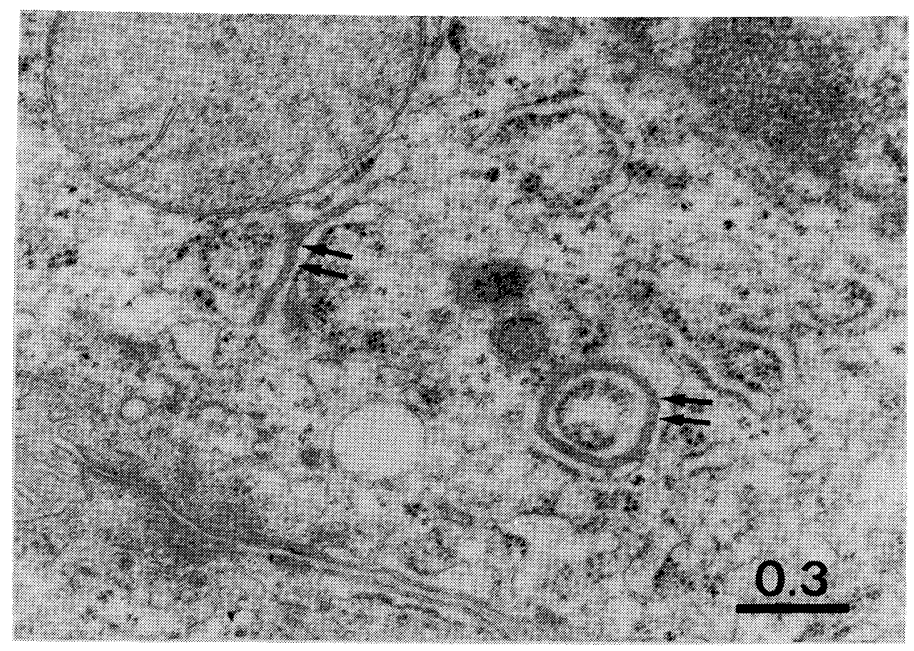

Fig. 5. Attached membrane-like structures in a hepatocyte of a marmoset infected with non-A, non-B hepatitis. 